\title{
CAKrRAWALA

\section{INDEKS HARGA SAHAM GABUNGAN \\ DI TINJAU DARI SISI EKONOMI MAKRO PADA BEI}

\author{
Novita Dwi Agustina ${ }^{1}$, Yuniningsih Yuniningsih ${ }^{2}$ \\ Universitas Pembangunan Nasional "Veteran" Jawa Timur ${ }^{1.2}$ \\ Correspondence Email: yuniningsih@upnjatim.ac.id
}

\begin{abstract}
ABSTRAK
Tujuan dari penelitian ini adalah untuk mengetahui pengaruh inflasi, suku bunga SBI, dan nilai tukar pada Indeks Harga Saham Gabungan (IHSG) dan volume perdagangan saham sebagai variabel interverning.

Sampel diambil dengan metode purposive sampling, dengan kriteria pemilihan sampel yaitu data IHSG akhir bulan (closing price), pada periode Januari 2016 - Oktober 2019 sejumlah 46 bulan. Jenis data yang digunakan dalam penelitian ini adalah data sekunder. Teknik analisis yang digunakan adalah analisis jalur.

Hasil penelitian ini menunjukkan bahwa inflasi berpengaruh non signifikan terhadap IHSG. Suku bunga SBI berpengaruh negatif signifikan terhadap IHSG. Dan nilai tukar rupiah berpengaruh positif signifikan terhadap IHSG. Serta, inflasi terhadap IHSG yang diinterverning oleh volume perdagangan saham berpengaruh negatif signifikan.
\end{abstract}

\section{ABSTRACT}

The purpose of this study was to determine the effect of inflation, SBI interest rates, and exchange rates on the Composite Stock Price Index (CSPI) and stock trading volume as interverning variables.

Samples were taken by purposive sampling method, with sample selection criteria that is the closing price of $\mathrm{JCl}$ data (closing price), in the period January 2016 - October 2019 a number of 46 months. The type of data used in this study is secondary data. The analysis technique used is path analysis.

The results of this study indicate that the research proves insignificant on CSPI. SBI interest rates have a significant negative effect on the CSPI. And the rupiah exchange rate is significantly positive for the CSPI. Also, the conversion to CSPI is different from the negative trading volume.

Keywords: Inflation, interest, rates, CSPI. 


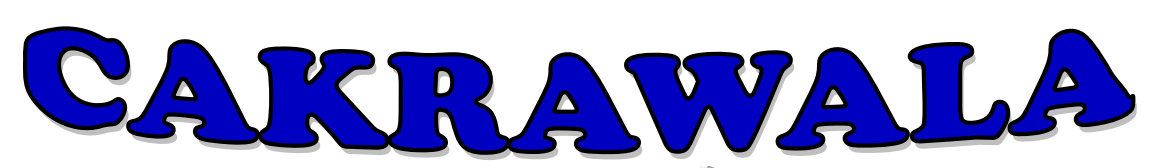

\section{Management Business Journal [C:M-B, J] Volume 3 Nomor 1 Mei Tahun 2020}

\section{PENDAHULUAN}

Keadaan perekonomian suatu negara dapat menjadi cerminan dari transaksi perekonomian secara keseluruhan di suatu negara, dengan digambarkan oleh iklim transaksi yang terjadi di pasar modal dan juga pasar uang. Pasar modal menjadi salah satu penggerak perekonomian, yang mana pasar modal dapat dijadikan tolak ukur bagi perekonomian suatu negara.

Pada saat adanya krisis finansial global yang berawal dari Amerika Serikat di tahun 2008 dan krisis finansial Eropa di tahun 2011, mempunyai pengaruh negatif pada kegiatan pasar modal berbagai negara-negara termasuk di Indonesia. Krisis keuangan dunia terjadi akibat adanya kebangkrutan beberapa perusahaan besar di Amerika Serikat, dengan dipicu oleh krisis kredit perumahan dan produk sekuritas. Dampaknya dari krisis finansial global di Indonesia yaitu dengan ditandai oleh jatuhnya harga saham di pasar modal.

Investasi melalui pasar modal menjadi hal yang diminati oleh setiap negara, karena perannya yang strategis bagi penguatan ketahanan suatu negara. Semakin baik tingkat perekonomian suatu negara, maka akan semakin baik pula tingkat kemakmuran masyarakatnya. Saham menjadi instrumen investasi bagi banyak investor untuk mendapatkan keuntungan. Nilai perusahaan sangat mempengaruhi investor dalam memutuskan investasi. salah satu indicator nilai perusahaan bisa dilihat dari harga saham, tingkat profitabilitas dan lain-lain ( $Y$ Yuniningsih, Pertiwi, \& Purwanto, 2019). Tingkat risiko pada setiap intrumen investasi akan selalu berbanding lurus dengan keuntungan yang akan diperoleh oleh para investor. Banyak faktor yang mempengaruhi investasi baik yang bersifat makro maupun mikro, fundamental maupun non fundamental, internal maupun eksternal (Yuniningsih Yuniningsih, Pratama, Widodo, \& Ady, 2019). Banyak para investor tertarik untuk menginvestasikan dananya dengan menanamkannya di pasar saham karena saham memiliki tingkat keuntungan yang tinggi berupa dividen dan capitan again. Akan tetapi keuntungan yang tinggi yang akan didapatkan dari investasi, akan sebanding dengan tingkat risiko tinggi yang akan didapat oleh para investor. Kondisi perkembangan pasar saham dapat dipantau melalui besarnya volume transaksi dan perkembangan Indeks Harga Saham Gabungan (IHSG) di bursa saham.

Pergerakan indeks harga saham gabungan dapat dipengaruhi oleh dua faktor yaitu faktor mikro ekonomi dan faktor makro ekonomi. Faktor mikro meliputi faktor ekonomi yang berkaitan dengan kondisi internal perusahaan. Sedangkan faktor makro ekonomi meliputi faktor ekonomi yang berada di luar perusahaan dan mempengaruhi naik turunnya kinerja perusahaan, meliputi pertumban GDP, produksi industri, tingkat suku bunga, pengangguran, nilai tukar, inflasi dan anggaran defisit.

Volume perdagangan saham merupakan salah satu indikator yang digunakan dalam analisis teknikal pada penelitian harga saham. Volume perdagangan saham dapat dijadkani instrumen untuk melihat reaksi pasar modal terhadap informasi pergerakan aktivitas volume perdagangan saham. Transaksi perdagangan saham perusahaan pada suatu sesi akan nampak pada volume perdagangannya, karena volume perdagangan menjadi gambaran pertemuan antara permintaan dan penawaran. Ketika terjadi inflasi yang tinggi akan meningkatkan biaya produksi perusahaan, sehingga akan mengurangi laba perusahaan. Ketika inflasi para investor akan lebih berhati-hati 


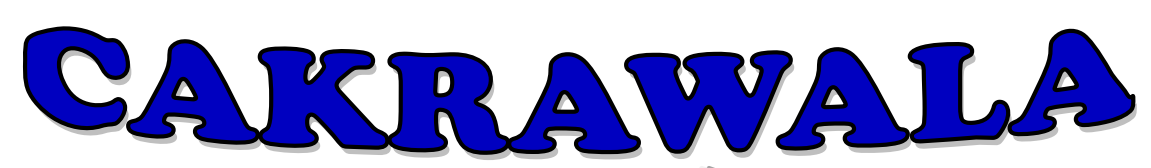

\section{Management Business Journal [CM:-BJ] Volume 3 Nomor 1 Mei Tahun 2020}

dalam memilih dan melakukan transaksi, investor cenderung menunggu untuk berinvestasi sampai keadaan pasar membaik. Sehingga hal ini akan menurunkan produktivitas permintaan saham, yang akan berdampak pada penurunan volume perdangan saham di pasar saham.

Selain inflasi, variabel lain yaitu tingkat suku bunga. Menurut Manurung, R (2016) suku bunga SBI adalah tingkat suku bunga yang ditetapkan oleh Bank Indonesia sebagai patokan bagi suku bunga simpanan dan pinjaman bagi bank ataupun lembaga-lembaga keuangan di seluruh Indonesia. Ketika suku bunga meningkat maka harga saham akan mengalami penurunan. Dan sebaliknya apabila tingkat suku bunga cenderung turun maka harga saham akan mengalami peningkatan. Peningkat suku bunga, pemilik modal dan investor cenderung akan mengalihkan modalnya ke pasar uang, tabungan atau deposito. Dikarenakan imbalan saham yang akan diterima lebih kecil dibandingkan imbalan suku bunga deposito, hal tersebut menyebabkan harga saham di pasar modal akan cenderung menurun.

Nilai tukar mata uang atau disebut kurs juga menjadi salah satu faktor makro ekonomi yang mempengaruhi harga saham. Menurut Murni, A (2010) nilai tukar rupiah merupakan nilai dari satu mata uang rupiah yang di translasikan ke dalam mata uang negara lain. Penguatan nilai tukar rupiah terhadap mata uang asing dapat menjadi sinyal positif bagi investor-investor. Kurs rupiah terhadap mata uang asing yang mengalami penguatan, mengakibatkan investor tertarik untuk berinvestasi ke pasar saham. Penguatan nilai rupiah menggambarkan bahwa perekonomian negara tersebut dalam keadaaan baik. Sebaliknya apabila kurs rupiah melemah terhadap mata uang asing, mengggambarkan bahwa perekonomian negara dalam keadaan yang kurang baik. Dalam keadaan ini, para investor cenderung enggan untuk berinvestasi di pasar saham mengingat risiko atau keuntungan yang akan didapatkannya, jadi hal ini akan mempengaruhi indeks harga saham.

Berdasarkan fenomena di atas, dapat dilihat bahwa Indeks Harga Saham Gabungan (IHSG) dapat dipengaruhi oleh beberapa faktor makro. Tujuan dari penelitian ini yaitu untuk menganalisis pengaruh Indeks Harga Saham Gabungan ditinjau dari sisi ekonomi makro pada Bursa Efek Indonesia (BEI). Adapun faktor-faktor ekonomi makro tersebut yaitu inflasi, tingkat suku bunga SBI, nilai tukar, dan volume perdagangan saham sebagai variabel interverning.

\section{METODE PENETITIAN}

Metode yang digunakan dalam penelitian ini yaitu menggunakan time series. Variabel ekonomi makro dalam penelitian ini yaitu inflasi, suku bunga SBI, dan nilai tukar. Dengan variabel interverneing volume perdagangan saham.

Populasi yang digunakan dalam penelitian ini adalah Indeks Harga Saham Gabungan (IHSG) periode Januari 2016 sampai Oktober 2019.

Teknik sampel yang digunakan yaitu purposive sampling. Purposive sampling merupakan merupakan teknik penentuan sampel dengan kriteria tertentu (Sugiyono, 2010). Kriteria pemilihan sampel pada penelitian ini adalah data IHSG akhir bulan (closing price), pada periode Januari 2016 - Oktober 2019 sejumlah 46 bulan. Sehingga sampel penelitian ini adalah indeks harga saham gabungan per bulan pada tahun 2016 - 2019 sejumlah 46 sampel data.

Jenis data yang digunakan dalam penelitian ini adalah data sekunder. Data sekunder dalam penelitian ini berupa indeks harga saham gabungan per bulan di pasar saham reguler, data volume 


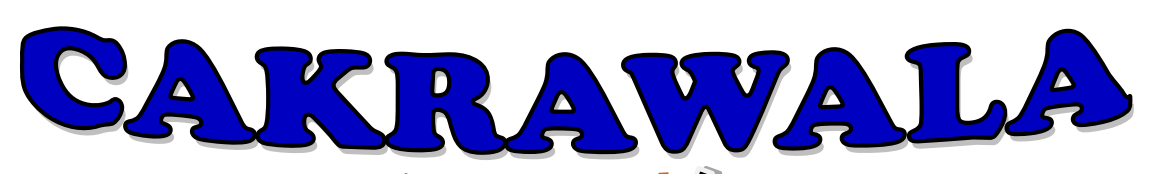

\section{Management Business Journal [CM:-B.] Volume 3 Nomor 1 Mei Tahun 2020}

perdagangan saham, data inflasi, data tingkat suku bunga $\mathrm{BI}$, dan data nilai tukar. Teknik analisis yang digunakan dalam penelitian ini adalah analisis jalur (path analysis). Menurut Retherford, R.D (1993) analisis jalur (path analysis) adalah suatu teknik untuk menganalisis hubungan sebab akibat yang tejadi pada regresi berganda jika variabel bebasnya mempengaruhi variabel tergantung tidak Page | - 525 - hanya secara langsung tetapi juga secara tidak langsung.

Sebelum melakukan analisis jalur (path analysis) dilakukan uji asumsi klasik untuk menghindari timbulnya penyimpangan (Ghozali, I 2011), meliputi uji normalitas, uji multikolinieritas, uji heterokedastisitas dan uji auto korelasi.

Berdasarkan hubungan antar variabel, maka model analisis jalurnya sebagai berikut :

Substruktural $1: \mathrm{Y} 1=\mathrm{P}_{\mathrm{y} 1 \times 1} \mathrm{X} 1+\mathrm{P}_{\mathrm{yi}} \mathrm{e} 1$

Keterangan :

$\mathrm{Y} 1$ = Volume perdagangan saham

$\mathrm{P}_{\mathrm{y} 1 \times 1}=$ Koefisien jalur variabel $\mathrm{Y} 1$ terhadap $\mathrm{X}$

$\mathrm{X} 1$ = Inflasi

$\mathrm{P}_{\mathrm{yi}} \mathrm{e} 1=$ Koefisien jalur standart eror terhadap $\mathrm{Y} 1$

Substruktural $2: \mathrm{Y} 2=\mathrm{P}_{\mathrm{y} 2 \mathrm{y} 1} \mathrm{Y} 1+\mathrm{P}_{\mathrm{y} 2 \times 1} \mathrm{X} 1+\mathrm{P}_{\mathrm{y} 2 \times 2} \mathrm{X} 2+\mathrm{P}_{\mathrm{y} 2 \times 3} \mathrm{X} 3+\mathrm{P}_{\mathrm{y} 2} \mathrm{e} 2$

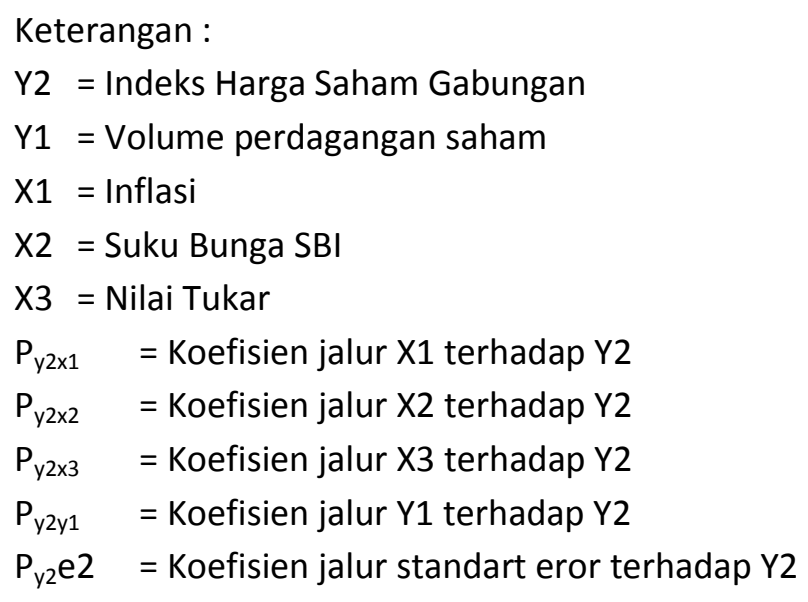

\section{HASIL PENELITIAN}

Penelitian ini menggunakan teknik analisis jalur (path analysis) untuk menguji hipotesis pengaruh langsung dan tidak langsung

\section{Merumuskan Persamaan Strukturalnya dan koefisien Jalur secara Parsial}

\section{A. Substruktural 1}

\section{Uji Koefisien Determinasi $\left(\mathbf{R}^{2}\right)$}

Koefisien determinasi menyangkut seberapa jauh kemampuan model dalam menerangkan variasi variabel dependen. Nilai koefisien determinasi yaitu diantara nol dan satu. Nilai $R^{2}$ yang kecil 


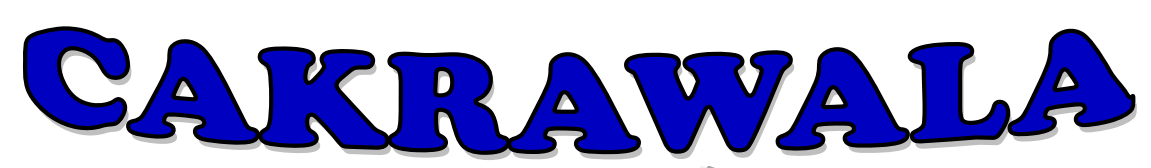

\section{Management Business Journal [CM:-B]] Volume 3 Nomor 1 Mei Tahun 2020}

menandakan bahwa kemampuan variabel-variabel independen dalam menjelaskan variabel dependen sangat terbatas. Uji koefisien determinasi untuk mengukur derajat hubungan antara tiap variabel $X$ terhaap variabel $Y$ secara parsial.

Tabel 1.

Uji Koefisien Determinasi $\left(\mathbf{R}^{2}\right)$ Substruktular 1 Model Summary

$\begin{array}{cccccc}\text { Model } & \mathrm{R} & \mathrm{R} \text { Square } & \begin{array}{c}\text { Adjusted } \\ \text { R Square }\end{array} & \begin{array}{c}\text { Std. Error of the } \\ \text { Estimate }\end{array} & \text { Durbin-Watson } \\ 1 & .772^{\mathrm{a}} & .596 & .556 & 363.62783 & 1.613\end{array}$

a. Predictors: (Constant), Nilai Tukar, Volume, BI Rate, Inflasi

b. Dependent Variable: IHSG

Sumber: SPSS, data diolah (Lampiran)

Berdasarkan tabel 4.1 nilai R-Square atau Koefisisen Determinasi $\left(R^{2}\right)=0,559$ berarti variabel Y (Indeks Harga Saham Gabungan) dipengaruhi oleh variabel-variabel independen volume perdagangan saham, Inflasi (X1), Suku bunga (X2) dan nilai tukar (X3), sebesar 59,6\%. Sisanya sebesar 40,4 \% dipengaruhi oleh variabel lain selain variabel-varibel independen dalam model tersebut.

\section{Uji F}

Uji $\mathrm{F}$ ini digunakan untuk mengetahui apakah variabel-variabel independen secara simultan berpengaruh signifikan terhadap variabel dependen. Apabila nilai $F$ hasil perhitungan lebih dari nilai $\mathrm{F}$ tabel maka hipotesis alternatif yang menyatakan bahwa semua variabel independen, secara simultan berpengaruh signifikan terhadap variabel dependen.

\section{Tabel 2.}

Uji F (Substruktural 1) ANOVA ${ }^{b}$

\begin{tabular}{ccccccc}
\hline & Model & Sum of Squares & Df & Mean Square & F & Sig. \\
1 & Regression & 7989100.996 & 4 & 1997275.249 & 15.105 & $.000^{\text {a }}$ \\
Residual & 5421233.142 & 41 & 132225.199 & & & \\
Total & $1.341 \mathrm{E} 7$ & 45 & & &
\end{tabular}

a. Predictors: (Constant), Nilai Tukar, Volume, BI Rate, Inflasi

b. Dependent Variable: IHSG

Sumber: SPSS, data diolah (Lampiran)

Berdasarkan Tabel 4.2 dengan $F$ test, menunjukkan bahwa nilai signifikansi (Sig.) = 0,000 lebih kecil dari 0,05 yang berarti Signifikan, hal ini dapat disimpulkan jika penggunaan model regresi dalam penelitian ini sesuai.

\section{Uji T hitung}

Uji t hitung pada dasarnya menunjukkan seberapa jauh pengaruh satu variabel independen secara individual menerangkan variabel-variabel terikat. Penggunaan parsial regresi dimaksudkan untuk mengetahui apakah variabel bebas secara individual mempunyai pengaruh terhadap variabel terikat dengan asumsi variabel yang lain itu konstan.

Tabel 3. 


\section{CAKrawala}

Management Business Journal [C,

Volume 3 Nomor 1 Mei Tahun 2020

Uji T Hitung (Substruktural 1) Hasil Regresi Berganda Coefficients ${ }^{a}$

\begin{tabular}{|c|c|c|c|c|c|c|c|c|}
\hline \multirow{2}{*}{\multicolumn{2}{|c|}{$\begin{array}{c}\text { Coefficients }{ }^{\mathrm{a}} \text { Mod } \\
\text { el }\end{array}$}} & \multicolumn{2}{|c|}{$\begin{array}{l}\text { Unstandardized } \\
\text { Coefficients }\end{array}$} & \multirow{2}{*}{$\begin{array}{c}\begin{array}{c}\text { Standardize } \\
\text { d } \\
\text { Coefficients }\end{array} \\
\text { Beta }\end{array}$} & \multirow[t]{2}{*}{$T$} & \multirow[t]{2}{*}{ Sig. } & \multicolumn{2}{|c|}{$\begin{array}{l}\text { Collinearity } \\
\text { Statistics }\end{array}$} \\
\hline & & $B$ & $\begin{array}{l}\text { Std. } \\
\text { Error }\end{array}$ & & & & $\begin{array}{c}\text { Toleranc } \\
\mathrm{e}\end{array}$ & VIF \\
\hline \multirow[t]{5}{*}{1} & (Constant) & $\begin{array}{c}788.62 \\
0\end{array}$ & $\begin{array}{c}1916.65 \\
6\end{array}$ & & .411 & $\begin{array}{c}.68 \\
3\end{array}$ & & \\
\hline & Volume & 2.284 & .752 & .339 & $\begin{array}{c}3.03 \\
7\end{array}$ & $\begin{array}{c}.00 \\
4\end{array}$ & .792 & $\begin{array}{c}1.26 \\
3\end{array}$ \\
\hline & Inflasi & $\begin{array}{c}- \\
207.27 \\
9\end{array}$ & 137.510 & -.176 & $\begin{array}{c}- \\
1.50 \\
7\end{array}$ & $\begin{array}{c}.13 \\
9\end{array}$ & .724 & $\begin{array}{c}1.38 \\
2\end{array}$ \\
\hline & BI Rate & $\begin{array}{c}- \\
215.40 \\
3\end{array}$ & 74.179 & -.320 & $\begin{array}{c}- \\
2.90 \\
4\end{array}$ & $\begin{array}{l}.00 \\
6\end{array}$ & .810 & $\begin{array}{c}1.23 \\
4\end{array}$ \\
\hline & Nilai Tukar & .461 & .126 & .436 & $\begin{array}{c}3.64 \\
6\end{array}$ & $\begin{array}{c}.00 \\
1\end{array}$ & .690 & $\begin{array}{c}1.44 \\
9\end{array}$ \\
\hline
\end{tabular}

a. Dependent Variable: IHSG

Sumber: SPSS, data diolah (Lampiran)

Persamaan Path

$Z_{\text {IHSG }}=2,284 Z_{\text {Volume }}-207,279 Z_{\text {Inflasi }}-215,403 Z_{\text {BI Rate }}+0,461 Z_{\text {Nilai Tukar }}$

Dari tabel 4.3 maka diketahui hasil uji t masing-masing variabel independen terhadap variabel dependen. Pada Hipotesis $1\left(\mathrm{H}_{1}\right)$, hasil dari variabel inflasi (X1) terhadap IHSG menunjukkan bahwa inflasi berpengaruh Non Signifikan terhadap IHSG, dengan koefisien path $=-207,279$ dimana nilai Sig. 0,139 lebih besar dari nilai 0,05 (5\%). Berdasarkan penjelasan diatas maka hasil penelitian tidak sesuai dengan hipotesis yang ada, karena dalam penelitian ini variabel inflasi memiliki hubungan non sisnifikan terhadap IHSG.

Hipotesis $2\left(\mathrm{H}_{2}\right)$, hasil dari variabel tingkat suku bunga (X2) terhadap IHSG menunjukkan bahwa Suku bunga (BI Rate) berpengaruh Signifikan Negatif terhadap IHSG, dengan koefisien path = -215,403 dimana nilai Sig. 0,006 lebih kecil dari nilai 0,05 (5\%). Berdasarkan penjelasan diatas maka hasil penelitian sesuai dengan hipotesis yang ada, karena dalam penelitian ini variabel suku bunga berpengaruh negatif signifikan terhadap IHSG.

Hipotesis $3\left(\mathrm{H}_{3}\right)$, hasil dari variabel nilai tukar $(\mathrm{X} 3)$ terhadap IHSG menunjukkan bahwa Nilai Tukar berpengaruh Signifikan Positif terhadap IHSG, dengan koefisien path $=0,461$ dimana nilai Sig. 0,001 lebih kecil dari nilai 0,05 (5\%). Berdasarkan penjelasan diatas maka hasil penelitian sesuai dengan hipotesis yang ada, karena dalam penelitian ini variabel nilai tukar berpengaruh positif signifikan terhadap IHSG.

Hipotesis $4\left(\mathrm{H}_{4}\right)$ menunjukkan bahwa volume perdagangan saham berpengaruh Signifikan Positif terhadap IHSG, dengan koefisien path $=2,284$ dimana nilai Sig. 0,004 lebih kecil dari nilai 


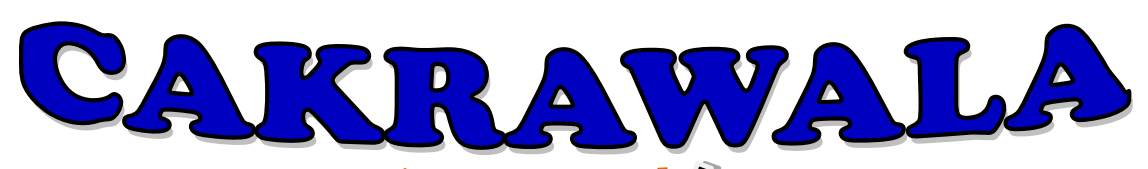

\section{Management Business Journal [CM:-BJ] Volume 3 Nomor 1 Mei Tahun 2020}

0,05 (5\%). Nilai signifikan dari volume perdagangan saham yang kurang dari 0,05 dapat diinterpretasi sebagai adanya pengaruh secara parsial dari volume perdagangan saham terhadap Indeks Harga Saham Gabungan (IHSG).

\section{B. Substruktural 2}

Uji Koefisien Determinasi $\left(\mathbf{R}^{2}\right)$

Tabel 4.

Uji Koefisien Determinasi (R2) Substruktular 2 Model Summary ${ }^{b}$

\begin{tabular}{|c|c|c|c|c|c|}
\hline Model & $\mathrm{R}$ & R Square & $\begin{array}{l}\text { Adjusted } \\
\text { R Square }\end{array}$ & $\begin{array}{l}\text { Std. Error of } \\
\text { the Estimate }\end{array}$ & Durbin-Watson \\
\hline 1 & $.310^{\mathrm{a}}$ & .096 & .075 & 77.88910 & .625 \\
\hline \multicolumn{6}{|c|}{ a. Predictors: (Constant), Inflasi } \\
\hline \multicolumn{6}{|c|}{ b. Dependent Variable: Volume } \\
\hline \multicolumn{6}{|c|}{ Sumber: SPSS, data diolah (Lampiran) } \\
\hline
\end{tabular}

Berdasarkan tabel 4.4 nilai R-Square atau Koefisisen Determinasi $\left(R^{2}\right)=0,096$ berarti variabel $Y$ (Volume Perdagangan Saham) dipengaruhi oleh variabel independen Inflasi sebesar 9,6 \%. Sisanya sebesar 90,4 \% dipengaruhi oleh variabel lain selain variabel-varibel independen dalam model tersebut.

\section{Uji F}

Tabel 5.

Uji F (Substruktural 2) ANOVA ${ }^{\text {b }}$

\begin{tabular}{|c|c|c|c|c|c|c|}
\hline & Model & Sum of Squares & Df & Mean Square & $\mathrm{F}$ & Sig. \\
\hline \multirow[t]{3}{*}{1} & Regression & 28337.900 & 1 & 28337.900 & 4.671 & $.036^{\mathrm{a}}$ \\
\hline & Residual & 266935.312 & 44 & 6066.712 & & \\
\hline & Total & 295273.212 & 45 & & & \\
\hline \multicolumn{7}{|c|}{ a. Predictors: (Constant), Inflasi } \\
\hline \multicolumn{7}{|c|}{ b. Dependent Variable: Volume } \\
\hline
\end{tabular}

Berdasarkan Tabel 4.5 dengan $\mathrm{F}$ test, menunjukkan bahwa nilai signifikansi (Sig.) = 0,036 lebih kecil dari 0,05 yang berarti Signifikan, hal ini dapat disimpulkan jika penggunaan model regresi dalam penelitian ini sesuai.

\section{Uji T Hitung}

Tabel 6.

Uji T Hitung (Substruktural 1) Hasil Regresi Berganda / Coefficientsa 


\section{CAKrawala}

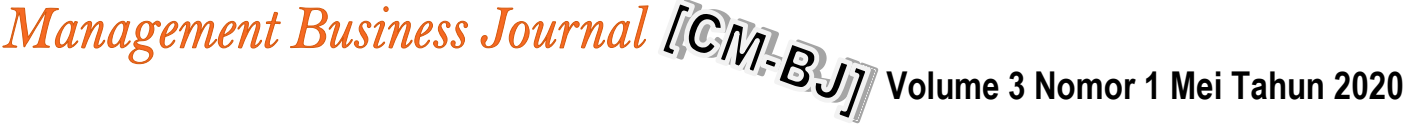

\begin{tabular}{|c|c|c|c|c|c|c|c|c|}
\hline & \multirow[t]{2}{*}{ Model } & \multicolumn{2}{|c|}{$\begin{array}{l}\text { Unstandardized } \\
\text { Coefficients }\end{array}$} & \multirow{2}{*}{$\begin{array}{c}\text { Standardized } \\
\text { Coefficients } \\
\text { Beta }\end{array}$} & \multirow[t]{2}{*}{$\mathrm{T}$} & \multirow[t]{2}{*}{ Sig. } & \multicolumn{2}{|c|}{$\begin{array}{l}\text { Collinearity } \\
\text { Statistics }\end{array}$} \\
\hline & & B & $\begin{array}{l}\text { Std. } \\
\text { Error }\end{array}$ & & & & Tolerance & VIF \\
\hline \multirow[t]{2}{*}{1} & (Constant) & 411.070 & 86.331 & & 4.762 & .000 & & \\
\hline & Inflasi & -54.154 & 25.057 & -.310 & -2.161 & .036 & 1.000 & 1.000 \\
\hline \multicolumn{9}{|c|}{ a. Dependent Variable: Volume } \\
\hline
\end{tabular}

Sumber: SPSS, data diolah (Lampiran)

Persamaan Path

$Z_{\text {Volume }}=-54.154 Z_{\text {Inflasi }}$

Berdasarkan hasil penelitian Hipotesis $4\left(\mathrm{H}_{4}\right)$ menunjukkan bahwa variabel inflasi berpengaruh negatif signifikan terhadap volume perdagangan saham, dengan koefisien path = 54,154 dimana nilai Sig. 0,036 lebih kecildari nilai 0,05 (5\%). Nilai signifikan dari inflasi yang kurang dari 0,05 dapat diinterpretasi sebagai adanya pengaruh secara parsial dari volume perdagangan saham terhadap Indeks Harga Saham Gabungan (IHSG).

\section{Diagram Jalur}

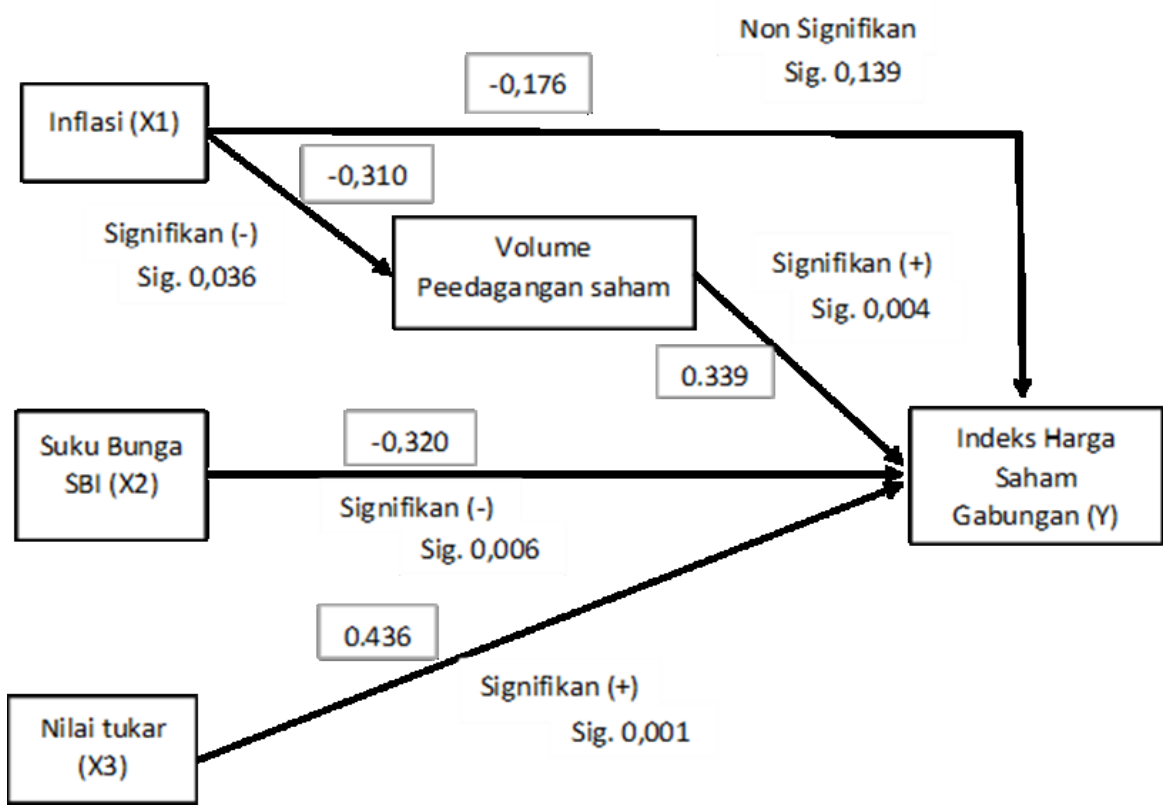

Gambar 1.

Diagram Path Besaran Pengaruh Antar Variabel

Perhitungan Pengaruh Langsung, Pengaruh Tidak Langsung, dan Pengaruh Total 


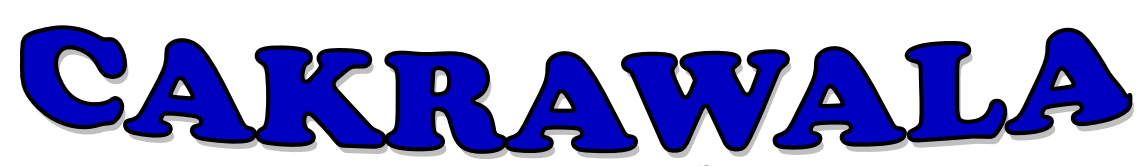

\section{Management Business Journal [CM:-B]] Volume 3 Nomor 1 Mei Tahun 2020}

Berdasarkan hasil analisis jalaur (path analisys), maka dapat dihitung pengaruh langsung, pengaruh tidak langsung, dan pengaruh total dari model yang telah dibuat. Perhitungan pengaruh langsung, tidak langsung, dan total tersebut dapat dilihat pada tabel 4.17:

Tabel 7.

Pengaruh Langsung, Pengaruh Tidak Langsung, dan Pengaruh Total

\begin{tabular}{lll}
\hline & Koefisien & Signifikansi \\
\hline Pengaruh Langsung: & & \\
Inflasi $\rightarrow$ IHSG & $-0,176$ & 0,139 \\
Volume Perd. Saham $\rightarrow$ IHSG & 0,339 & 0,004 \\
Inflasi $\rightarrow$ Volume Perd. Saham & $-0,310$ & 0,036 \\
Pengaruh Tidak Langsung: & & \\
Inflasi $\rightarrow$ Volume Perd. Saham $\rightarrow$ IHSG & $(-0,310) \times(0,339)=-0,105$ & Signifikan \\
Pengaruh Total : & & \\
Inflasi $\rightarrow$ IHSG (Inflasi $\rightarrow$ Volume Perd. & $(-0,176) \times(-0,105)=-0,018$ \\
Saham $\rightarrow$ IHSG) & & \\
\hline
\end{tabular}

Diketahui pengaruh langsung yang diberikan inflasi terhadap IHSG dengan koefisien beta sebesar $-0,176$, dimana nilai signifikannya 0,139 . Volume perdagangan saham terhadap IHSG dengan koefisien beta sebesar 0.339 , dimana nilai signifikannya sebesar 0,004. Inflasi terhadap volume perdagangan saham dengan koefisien beta -0,310, dimana nilai signifikannya sebesar 0,036.

Sedangkan pengaruh tidak langsung inflasi melalui volume perdagangan saham terhadap IHSG adalah perkalian antara nilai koefisien beta inflasi terhadap volume perdagangan saham dengan koefisien beta volume perdagangan saham terhadap IHSG yaitu : $(-0,310) \times(0,339)=-0,105$. Hasil dari pengaruh tidak langsung yaitu signifikan.

Maka pengaruh total yang diberikan inflasi terhadap IHSG adalah pengaruh langsung ditambah dengan pengaruh tidak langsung yaitu :

$(-0,176) \times(-0,105)=-0,018$.

Berdasarkan hasil perhitungan diatas dapat diketahui bahwa nilai pengaruh tidak langsung lebih besar dibandingkan pengaruh langsung. Hal ini karena pengaruh tidak langsung memiliki koefisien yang lebih besar daripada koefisien pengaruh langsung, nilai koefisien pengaruh tidak langsung sebesar -0,105 dan pengaruh langsung -0,176 $(-0,176<-0,105)$, hasil ini menunjukkan bahwa secara tidak langsung inflasi melalui variabel interverning volume perdagangan saham mempunyai pengaruh yang signifikan terhadap Indeks Harga Saham Gabungan (IHSG).

\section{PEMBAHASAN}

\section{Pengaruh Inflasi (X1) terhadap Indeks Harga Saham Gabungan (Y)}

Berdasarkan hasil penelitian yang dilakukan dapat diketahui bahwa inflasi berpengaruh non signifikan terhadap Indeks Harga Saham Gabungan (IHSG) periode Januari 2016 - Oktober 2019. Hasil ini dapat diartikan bahwa meningkatnya laju tingkat inflasi tidak berpengaruh terhadap Indeks Harga Saham Gabungan (IHSG)

Inflasi berpengaruh non signifikan terhadap IHSG, hal ini disebabkan naiknya tingkat inflasi akan mendorong depresiasinya nilai tukar rupiah terhadap mata uang asing. Seperti diketahui, nilai tukar 


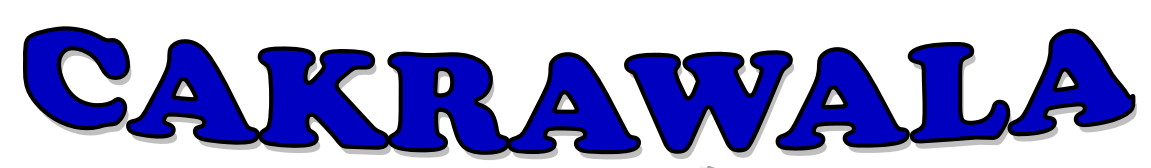

\section{Management Business Journal [CM:-B]] Volume 3 Nomor 1 Mei Tahun 2020}

berdasarkan pendekatan Purchasing Power Parity menyatakan bahwa perbedaan inflasi dalam negeri dan luar negeri akan diikuti oleh depresiasi mata uang domestik terhadap mata uang asing dilakukan dengan dua cara. Menurut versi relatif yaitu melalui hubungan harga dan nilai tukar. Yaitu apabila tingkat inflasi semakin tinggi di Indonesia berarti semakin besar selisih inflasi yang terjadi antara Indonesia dengan negara lain. Kondisi ini akan berdampak pada depresiasinya nilai tukar rupiah terhadap mata uang asing. Dengan depresiasi rupiah akan mendorong meningkatnya surplus neraca perdagangan dan pada akhirnya akan meningkatkan harga saham. Dari uraian diatas menunjukkan bahwa inflasi tidak berpengaruh signifikan terhadap keputusan para investor dalam melakukan transaksi investasi dipasar saham, sehingga tidak akan berpengaruh signifikan terhadap pergerakan indeks harga saham gabungan.

Hasil penelitian ini sesuai dengan penelitian yang dilakukan oleh Megawati, N dan Salim, M.N (2018) hasil penelitian menunjukkan bahwa Inflasi tidak memberikan pengaruh signifikan terhadap Indeks Harga Saham Gabungan (IHSG). Hal ini terjadi karena selama periode pengamatan tingkat inflasi berada dalam kategori inflasi ringan karena berada di bawah $10 \%$ (creeping inflation). Sehingga inflasi tidak berpengaruh terhadap kinerja perusahaan yang terdaftar di Bursa Efek Indonesia (BEI). Hasil penelitian tersebut menyatakan bahwa stabilnya inflasi membuat para investor tidak terlalu memperhatikan komponen inflasi dalam mempertimbangkan pembelian ataupun penjualan saham. Sehingga perubahan inflasi tidak berdampak secara nyata terhadap perubahan indeks harga saham gabungan. Tidak signifikannya pengaruh inflasi terhadap indeks harga saham tersebut juga bisa disebabkan karena para investor lebih banyak mempertimbangkan faktor-faktor lain seperti faktor fundamental perusahaan.

\section{Pengaruh Suku Bunga (X3) terhadap Indeks Harga Saham Gabungan (Y)}

Berdasarkan hasil penelitian yang dilakukan dapat diketahui bahwa suku bunga berpengaruh negatif signifikan terhadap Indeks Harga Saham Gabungan (IHSG) periode Januari 2016 - Oktober 2019. Hasil ini sesuai dengan hipotesis bahwa variabel suku bunga berpengaruh negatif terhadap IHSG. Sehingga hal ini mengidentifikasikan bahwa terjadinya perubahan yang ditunjukkan oleh suku bunga akan diikuti oleh peningkatan ataupun penurunan Indeks Harga Saham Gabungan.

Weston dan Brigham (1994) mengemukaan teori bahwa tingkat suku bunga mempunyai pengaruh yang besar terhadap harga saham. Suku bunga yang makin tinggi dapat memperlesu perekonomian, menaikkan biaya bunga dengan demikian menurunkan laba perusahaan, dan menyebabkan para investor menjual saham dan mentransfer dana ke pasar obligasi ataupun pasar uang. Hal ini sesuai teori yang dikemukakan oleh Tandelilin (2001:48) bahwa perubahan suku bunga akan mempengaruhi harga saham secara terbalik, ceteris paribus. Pengaruh tingkat suku bunga Sertifikat Bank Indonesia (SBI) yang signifikan menandakan bahwa pergerakan tingkat suku bunga memberikan pengaruh besar terhadap pengambilan keputusan investor. Jika suku bunga tinggi, maka masyarakat akan mengalihkan investasinya dari pasar modal (saham) ke sektor lain, seperti pada perbankan (deposito maupun tabungan). 


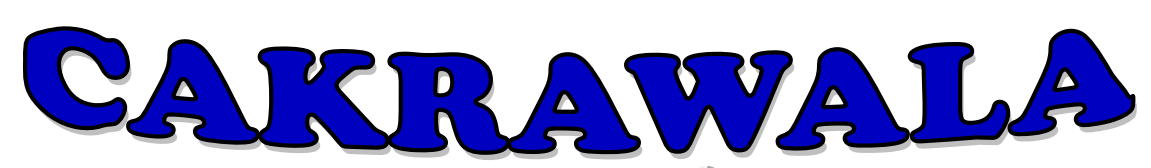

\section{Management Business Journal [CM:-B]] Volume 3 Nomor 1 Mei Tahun 2020}

Hasil penelitian ini sesuai dengan penelitian yang dilakukan oleh Nurwani (2016) yang menyatakan bahwa suku bunga SBI berpengaruh negatif dan signifikan terhadap pergerakan Indeks Harga Saham Gabungan (IHSG). Tingkat suku bunga yang tinggi akan menjadi sinyal negatif terhadap indeks harga saham gabungan. Tingkat suku bunga yang tinggi akan meningkatkan suku bunga yang harus dibayarkan sehingga dapat menurunkan laba perusahaan. Selain itu tingkat suku bunga yang tinggi juga menyebabkan investor menarik investasinya pada pasar saham dan memindahkannya pada investasi berupa deposito ataupun tabungan.

\section{Pengaruh Nilai Tukar Rupiah (X3) terhadap Indeks Harga Saham Gabungan (Y)}

Berdasarkan hasil penelitian yang dilakukan dapat diketahui bahwa nilai tukar rupiah berpengaruh positif signifikan terhadap Indeks Harga Saham Gabungan (IHSG) periode Januari 2016 - Oktober 2019. Hasil ini sesuai dengan hipotesis bahwa variabel nilai tukar berpengaruh positif terhadap IHSG. Menurut Granger, et. al (1998) secara teoritis perbedaan arah hubungan antara kurs dan harga saham dapat dijelaskan melalui pendekatan tradisional.

Teori pendekatan tradisional menyatakan bahwa hubungan antara nilai tukar dengan harga saham adalah positif, hal ini menandakan sinyal positif terhadap pergerakan indeks harga saham gabungan. Yang dimana perubahan nilai tukar mempengaruhi kompetitifnya suatu perusahaan. Hal ini sebagai efek dari fluktuasi nilai tukar yang mempengaruhi pendapatan dan biaya operasional suatu perusahaan, yang pada akhirnya menyebabkan perubahan pada harga sahamnya. Dengan kata lain, pergerakan nilai tukar dapat mempengaruhi nilai pembayaran (penerimaan) masa depan suatu perusahaan yang didominasi oleh mata uang luar negeri.

Hasil yang diperoleh ini konsisten dengan teori yang dikemukakan oleh Tandelin (2001), yang menyatakan bahwa menguatnya kurs rupiah terhadap dolar US merupakan sinyal positif bagi perekonomian yang mengalami inflasi. Menguatnya kurs rupiah terhadap dolar US dapat menurunkan biaya produksi terutama biaya impor bahan baku dan akan diikuti menurunnya tingkat bunga yang berlaku. Sehingga hal ini akan memberikan dampak positif pada laba perusahaan yang akhirnya menaikkan pendapatan per lembar saham.

Hasil penelitian ini sesuai dengan yang dikemukakan oleh Manurung, R (2016) yang hasil penelitiannya menyatakan bahwa variabel nilai tukar rupiah bepengaruh positif signifikan terhadap Indeks Harga Saham Gabungan (IHSG). Menguatnya mata uang asing (dollar) terhadap rupiah merupakan gambaran bahwa perekonomian sedang dalam keadaan kurang baik, sehingga para investor akan cenderung takut untuk berinvestasi pada pasar saham. Sebaliknya, apabila nilai tukar rupiah menguat terhadap mata uang asing (dolar) maka menggambarkan bahwa perekonomian negara dalam keadaan baik. Sehingga para investor akan lebih tertarik dan yakin untuk berinvestasi dalam bentuk saham karena pada saat itu kondisi perekonomian dalam keadaan bagus.

\section{Pengaruh Inflasi terhadap Indeks Harga Saham Gabungan (IHSG) melalui Volume Perdagangan Saham Gabungan}

Berdasarkan hasil penelitian yang dilakukan dapat diketahui bahwa tingkat inflasi yang dimediasi oleh volume perdagangan saham memberikan kontribusi yang signifikan terhadap variabel Indeks Harga Saham Gabungan. Hasil dari penelitian ini menunjukkan bahwa inflasi berpengaruh negatif 


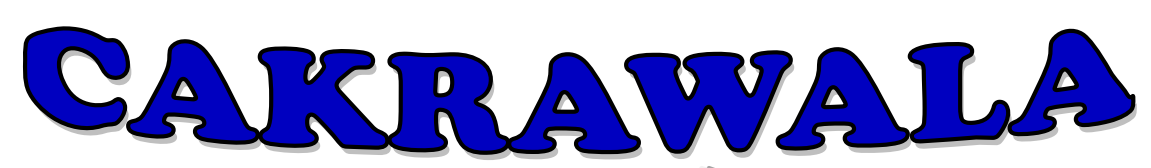

\section{Management Business Journal [CM:-BJ]] Volume 3 Nomor 1 Mei Tahun 2020}

dan signifikan terhadap Indeks Harga Saham Gabungan, ketika dimediasi oleh volume perdagangan saham. Sehingga hal ini mengidentifikasikan bahwa terjadinya perubahan yang ditunjukkan oleh inflasi akan berpengaruh terhadap volume perdagangan saham yang selanjutnya akan diikuti oleh pergerakan Indeks Harga Saham Gabungan.

Hasil penelitian ini menunjukkan bahwa volume perdagangan saham berperan sebagai variabel mediasi antara variabel inflasi dengan variabel indek harga saham gabungan (IHSG). Hal tersebut menunjukkan apabila inflasi meningkat akan berpengaruh terhadap penurunan transaksi volume perdagangan saham. Pengaruh tersebut merupakan informasi yang bernilai buruk (bad news) oleh investor. Sehingga pada investor akan enggan melakukan investasi dipasar saham sehingga menyebabkan tingkat permintaan saham menurun. Hal tersebut akan sangat berpengaruh terhadap pergerakan Indeks Harga Saham Gabungan, tingkat permintaan saham yang menurun, sedangkan tingkat penawaran saham meningkat akan menyebabkan menurunnya pergerakan Indeks Harga Saham Gabungan (IHSG).

Tandelilin (2010:248) mengemukakan bahwa pendekatan volume perdagangan saham dapat digunakan sebagai proksi reaksi pasar. Argumen yang dikemukakan adalah volume perdagangan saham lebih merefleksikan aktivitas investor karena adanya suatu informasi baru melalui penjumlahan saham yang diperdagangkan. Volume perdagangan merupakan salah satu indikator likuiditas saham atas suatu informasi yang ada dalam pasar. Menurut Husnan (2009:307) aktivitas volume perdagangan digunakan untuk melihat tindakan investor individual dalam menilai informasi mengenai harga dan volume yang terdapat di pasar dan mengakibatkan keputusan pembelian dan penjualan saham. Menurut (Samsul, 2015: 269) informasi mengenai pergerakan volume perdagangan di pasar dapat direspon sebagai suatu informasi yang bernilai baik (good news) dan informasi yang bernilai buruk (bad news) oleh investor.

Hasil penelitian ini sesuai dengan yang dikemukakan oleh Pangaribuan, H (2014) yang hasil penelitiannya menyatakan bahwa perubahan tingkat inflasi yang dimediasi oleh oleh volume perdagangan saham memberikan kontribusi yang signifikan terhadap Indeks Harga Saham Gabungan (IHSG). Dimana apabila tingkat inflasi yang terjadi meningkat atau naik maka akan mempengaruhi volume perdagangan saham menurun dan IHSG akan cenderung melemah, sehingga lebih baik para investor atau trader index untuk masuk pada saat inflasi relatif (atau diprediksi akan rendah) dan tentunya dengan bantuan analisa fundamental atau teknikal lainnya.

\section{KESIMPULAN}

Hasil penelitian ini menunjukkan bahwa Inflasi tidak memiliki pengaruh signifikan terhadap Indeks Harga Saham Gabungan. Inflasi berpengaruh non signifikan terhadap IHSG, hal ini disebabkan naiknya tingkat inflasi akan mendorong depresiasinya nilai tukar rupiah terhadap mata uang asing.

Suku bunga SBI memiliki pengaruh negatif dan signifikan terhadap Indeks Harga Saham Gabungan. Hasil ini sesuai dengan hipotesis bahwa variabel suku bunga berpengaruh negatif terhadap IHSG. Sehingga hal ini mengidentifikasikan bahwa terjadinya perubahan yang ditunjukkan oleh suku bunga akan diikuti oleh peningkatan ataupun penurunan Indeks Harga Saham Gabungan. 


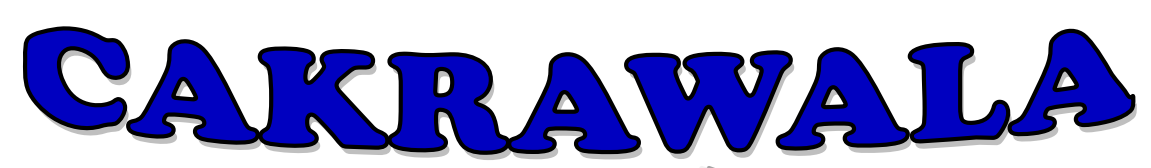

\section{Management Business Journal [CM:-B]] Volume 3 Nomor 1 Mei Tahun 2020}

Nilai tukar memiliki pengaruh positif dan signifikan terhadap Indeks Harga Saham Gabungan (IHSG) periode Januari 2016 - Oktober 2019, dan Inflasi terhadap Indeks Harga Saham Gabungan yang diinterverning oleh volume perdagangan saham menunjukkan bahwa inflasi berpengaruh negatif dan signifikan terhadap Indeks Harga Saham Gabungan, ketika dimediasi oleh volume perdagangan saham. Sehingga hal ini mengidentifikasikan bahwa terjadinya perubahan yang ditunjukkan oleh inflasi akan berpengaruh terhadap volume perdagangan saham yang selanjutnya akan diikuti oleh pergerakan Indeks Harga Saham Gabungan.

\section{REKOMENDASI}

Diharapkan para investor hendaknya memperhatikan tingkat suku bunga, nilai tukar rupiah, dan volume perdagangan saham, karena faktor-faktor tersebut memberikan kontribusi signifikan terhadap pergerakan Indeks Harga Saham Gabungan. Dan, Bagi peneliti selanjutnya diharapkan menambah jumlah sampel dan variabel-variabel lainnya. Tidak hanya dengan variabel makro ekonomi, melainkan juga menggunakan variabel mikro ekonomi, sehingga hasil yang didapatkan lebih maksimal.

\section{DAFTAR REFERENSI}

Ghozali, I. 2011. "Aplikasi Analisis Multivariate Dengan Program SPSS". Semarang: Badan Penerbit Universitas Diponegoro.

Granger C. W., Huang B. and Yang C. 1998."A Bivariate Causality Between Stock Prices And Exchange Rates: Evidence from Recent Asian Flu". The Quarterly Review Of Economics And Finance. Volume 40:337-354

Husnan, S. 2009. Dasar-dasar Teori Portofolio \& Analisis Sekuritas. Yogyakarta: UPP STIM YKPN. Manurung, R. 2016. Pengaruh Inflasi, Suku Bunga Dan Kurs Terhadap Indeks Harga Saham Gabungan Pada Bursa Efek Indonesia. Purwokerto: Jurnal Ekonomi, Vol 19 No 4.

Megawati, N. \& Salim, M.N. 2018. Pengaruh Variabel Makro Ekonomi terhadap Indeks Harga Saham Gabungan (IHSG). Media Ekonomi. Vol. 26 No. 1 April 2018 :47-54.

Murni, A. 2010. Pengaruh Faktor Makro Ekonomi Terhadap Indeks Harga Saham Gabungan dengan Volume Perdagangan sebagai Variabel Intervening (Studi Kasus di BEJ Periode Januari 2004 Desember 2008). Jurnal economic, Volume 4 No. 2.

Nurwani. 2016. Analisis Pengaruh Inflasi, Nilai Tukar Rupiah, Dan Suku Bunga SBI Terhadap Pergerakan Indeks Harga. E-Jurnal Universitas Muhammadiyah

Pangaribuan, H . 2014. Analisis Pengaruh Perubahan Inflasi terhadap Indeks Harga Saham dengan

Volume Perdagangan sebagai Variabel Perantara (Suatu Studi di Indonesia). Jurnal Ekonomi dan Bisnis. Vol. 4. No. 1

Retherford, Robert D. 1993. Statistical Models For Causal Analysis. Program on Population East West Center , Honolulu, Hawaii.

Samsul, M. 2015. Pasar Modal dan Manajemen Portofolio. Erlangga, Jakarta.

Sugiyono. 2014. Metode Penelitian Pendidikan Pendekatan Kuantitatif, Kualitatif, dan R\&D. Bandung: Alfabeta.

Tandelilin, E. 2001. Analisis Investasi dan Manajemen Portofolio, Yogyakarta : BPFE 


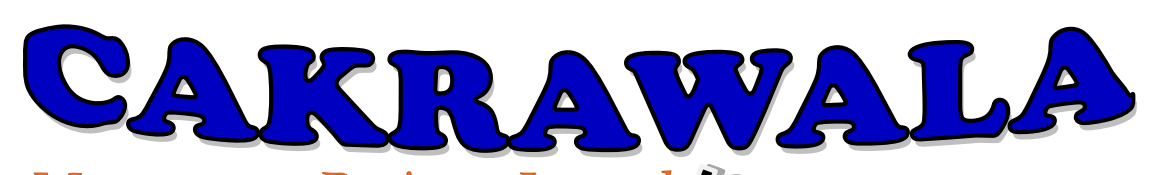

Management Business Journal [CM:-B]] Volume 3 Nomor 1 Mei Tahun 2020

Tandelilin, E. 2010. Portofolio dan Investasi: Teori dan Aplikasi. Edisi 1. Kanisius. Yogyakarta.

Weston J. Fred and Brigham F. Eugene .1994. Essential Of Managerial Finance, Tenth Edition.

New York: The Dryden Press

Yuniningsih, Y, Pertiwi, T., \& Purwanto, E. (2019). Fundamental factor of financial management in Page | - 535 determining company values. Management Science Letters, 9(2), 205-216. 